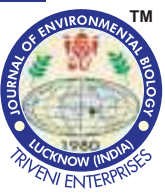

\title{
Development of species-specific primers for detection of Xanthomonas campestris pv. campestris causing black rot of crucifers
}

\section{Authors Info}

R. Kiran ${ }^{1 *}$, A. Kandan ${ }^{2}$,

P. Kumar', D. Singh ${ }^{3}$, J. Akhtar', B. Singh ${ }^{1}$ and S.C. Dubey

'Division of Plant Quarantine, ICAR-National Bureau of Plant Genetic Resources, New Delhi-110 012, India

${ }^{2}$ Division of Insect Ecology, ICAR-National Bureau of Agricultural Insect Resources, Bengaluru-560 024, India

${ }^{3}$ Division of Plant Pathology, ICAR-Indian Agricultural Research Institute, New Delhi-110 012, India

*Corresponding Author Email : paurajkiran@gmail.com

\section{Edited by}

Dr. Sumati Gaumat

\section{Reviewed by}

Dr. Baswaraj Raigond

Dr. K. Sakthivel

\section{Abstract}

Aim : Black rot of crucifers caused by Xanthomonas campestris pv. campestris (Pammel) Dowson (Xcc) is a major seed-borne disease. The present study aimed to develop a rapid diagnostic protocol for the specific and sensitive detection of this pathogen.

Methodology : Aspecific primer set was designed based on rpfgene and optimization of PCR condition was done for specific detection of $X c c$. Sensitivity of PCR for primer set was then determined by diluting the Xcc DNAand cells.

Results : Specific primer set was able to amplify a specific band of $304 \mathrm{bp}$ in all 11 isolates of $X c c$ but failed to amplify other Xanthomonas species and one each of Ralstonia solanacearum, Erwinia caratovora subsp. caratovora, Bacillus subtilis, Pseudomonas fluorescens and $P$. aeruginosa. The primer set was highly sensitive as it was able to detect $10 \mathrm{pg} \mathrm{\mu l}^{-1}$ bacterial DNA and up to $3 \times 10^{3} \mathrm{CFU} \mathrm{ml} \mathrm{l}^{-1}$ corresponding to 12 viable cells of $X c c$ which were used as template for PCR reaction.

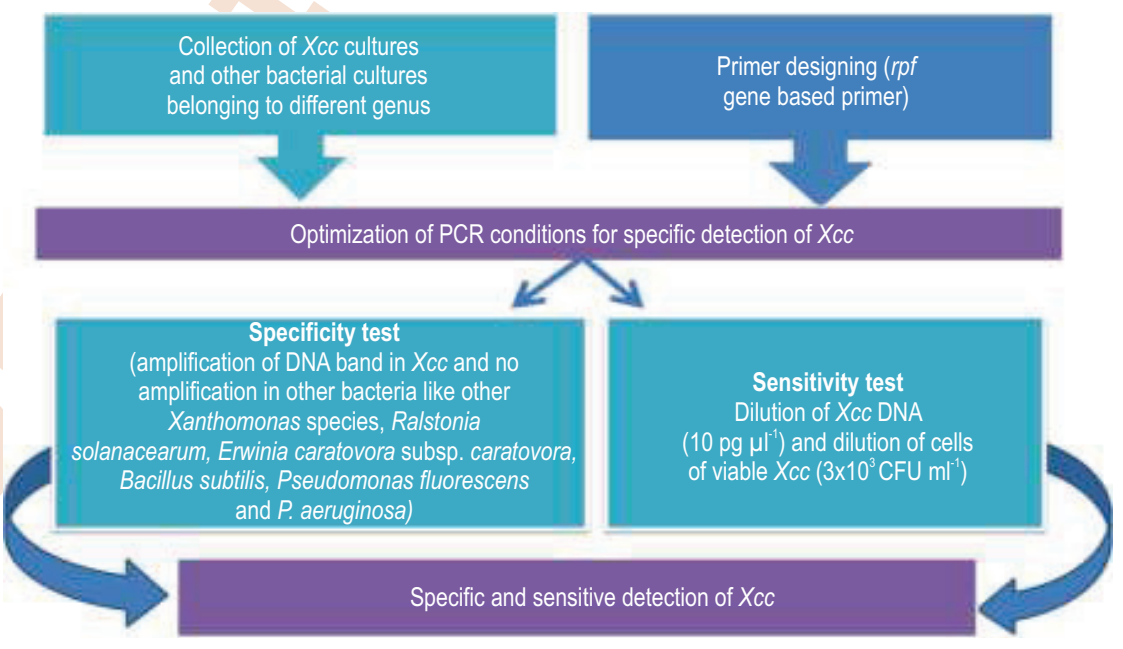

Interpretation : The results suggest that develope d PCR primers are highly specific and sensitive and it can be used to detect the pathogen at an early stage of infection for disease management.

Key words: Black rot, Diagnostic protocol, pv. campestris, rpfgene, Xanthomonas campestris

How to cite: Kiran, R., A. Kandan, P. Kumar, D. Singh, J. Akhtar, B. Singh and S.C. Dubey: Development of species-specific primers for detection of Xanthomonas campestris pv. campestris causing black rot of crucifers. J. Environ. Biol., 40, 105-110 (2019). 


\section{Introduction}

Xanthomonas campestris pv. campestris (Pammel) Dowson $(X c c)$ causing black rot of crucifers is a major seed-borne disease of crucifers worldwide (William, 1980). The pathogen initially produces marginal chlorotic spots on the leaves followed by darkening or blackening of mid rib and veins (Cook et al., 1952). Xcc produces an extracellular polysaccharide (EPS) called xanthan, which obstructs the xylem and causes necrosis of tissues and severe leaf wilting (Williams, 1980). The disease reduces seed vigour, quality of curd and heads in cauliflower and cabbage, respectively, resulting in considerable yield loss of 10 50\% (Dhar and Singh, 2014). Therefore, specific and rapid detection of Xcc in seeds and plants is essential to prevent introduction and spread of disease.

The classical methods for detection of $X c c$ in seed lots and plants are based on selective media, serological techniques and grow out test. However, these methods are time consuming and cumbersome as compared to PCR based detection methods. PCR based detection methods of plant pathogens have been shown to hold great promise in last two decades (Henson and French, 1993; Singh and Dhar, 2011; Singh et al., 2014; Kumar et al., 2017). It is well known that rpf (regulation of pathogenicity factors) gene cluster, which is responsible for regulation of pathogenicity factors as it co-ordinates regulation of extracellular enzymes, extracellular polysaccharide synthesis and diffusible signal factor (DSF) signal synthesis (Dow and Daniels, 1994; O'Cornell et al., 2013). It has been demonstrated by transposon mutagenesis that at least eight genes ( $r p f A$ to $H$ ) exists, which coordinates reduction in the levels of all extracellular enzymes tested (Tang et al., 1991).

The rpfH gene, which encodes elements of twocomponent sensory-transduction system (Tang et al., 1991; Slater et al., 2000; Dow et al., 2000), is present in Xcc and X. campestris. pv. euvasicatoria (Xcv), while absent in Xanthomonas axonopodis pv. citri (Xac) and X. oryzae pv. oryzae (Xoo) (Potnis et al., 2011). Therefore, specific primers were designed from $r p f H$ region to prevent cross species amplification in PCR. The aim of the present study was to develop a sensitive and specific PCR based assay for the detection of Xcc.

\section{Materials and Methods}

Bacterial cultures : Ten isolates of $X c c$ used were isolated from infected cabbage and cauliflower leaves obtained from different regions of India and one isolate was obtained during post entry quarantine inspection of cabbage, which was imported from China (Table 1). Diseased portion of leaf was surface sterilized using $1 \%$ sodium hypochlorite for 30 sec followed by $70 \%$ ethanol for $30 \mathrm{sec}$ and two times washing with distilled water for one minute each. Small diseased portion from diseased leaf was chopped with the help of sterilized blade on a clean glass slide having a drop of water and allowed to ooze out bacteria. Now, with the help of loop, this water was streaked on Nutrient Sucrose Agar
(NSA) medium. Yellow mucoid, glistering and convex colonies were obtained. These colonies were further sub-cultured into fresh media for obtaining pure colonies of $X c c$. These cultures were maintained on Yeast Dextrose Carbonate Agar (YDCA) medium (1\% yeast extract, $2 \%$ dextrose, $2 \%$ calcium carbonate and $1.5 \%$ agar) at $4^{\circ} \mathrm{C}$ for further use. Cultures of other bacteria viz. $X$. campestris. pv. euvasicatoria, $X$. oryzae pv. oryzae, $X$. axonopodis pv. punicae, $X$. citri subsp. citri, Ralstonia solanacearum, Erwinia caratovora subsp. caratovora, Bacillus subtilis, Pseudomonas fluorescens and Pseudomonas aeruginosa were procured from Bacteriology Laboratory, Division of Plant Pathology, ICAR-Indian Agricultural Research Institute, New Delhi, The Microbial Type Culture Collection and Gene Bank, Chandigarh and ICAR-National Bureau of Agriculturally Important Microorganisms, Mau, India (Table 1).

Extraction of Genomic DNA : Pure culture of eleven isolates of $X c c$ and other test bacteria ( $X$. campestris. pv. euvasicatoria, $X$. oryzae pv. oryzae, $X$. axonopodis pv. punicae, $X$. citri subsp. citri, Ralstonia solanacearum, Erwinia caratovora subsp. caratovora, Bacillus subtilis, Pseudomonas fluorescens and Pseudomonas aeruginosa) were inoculated in pre-autoclaved $15 \mathrm{ml}$ tube containing $5 \mathrm{ml}$ nutrient sucrose broth media, incubated at $28^{\circ} \mathrm{C}$ for $24 \mathrm{hrs}$ at $140 \mathrm{rpm}$ and DNA was extracted as described by Pitcher et al. (1989).

Primer design and PCR amplification : A set of forward and reverse primers, rpfH_F 5'AGTTGCAGCAGCTGTTCT3' and rpfH_R 5'ATAGCACGTATTGGCAGGG3', respectively, was designed from an $r p f H$ region of $r p f$ gene family of $X$. campestris pv. campestris strain ATCC 33913 chromosome (NC_003902.1), which predicted a PCR products of $304 \mathrm{bp}$. DNA sequences from $\mathrm{rpfH}$ gene were randomly selected from the draft genome and a standard nucleotide BLASTN search was performed on NCBI database (http://www.ncbi.nlm.nih.gov). Through BLASTN analysis, regions unique to $X c c$ were selected to provide specific target sequences for specific primer design. The primers were designed using PrimerQuest Tool of IDT (https://eu.idtdna.com/ Primer Quest). PCR amplification was performed with a final volume of $25 \mu$ l containing $2.5 \mu \mathrm{l}$ of $10 \mathrm{X}$ reaction buffer, $0.2 \mathrm{mM}$ dNTPs mix, 1 U Taq DNA polymerase (New England BioLabs), 10

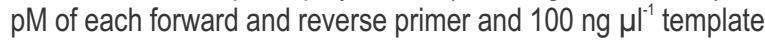
DNA. The PCR programme consisted of initial denaturation at $95^{\circ} \mathrm{C}$ for $3 \mathrm{~min}$ followed by 33 cycles at $95^{\circ} \mathrm{C}$ for $30 \mathrm{sec}, 63^{\circ} \mathrm{C}$ for $45 \mathrm{sec}$ and $72^{\circ} \mathrm{C}$ for $45 \mathrm{sec}$ and a final extension at $72^{\circ} \mathrm{C}$ for $5 \mathrm{~min}$. PCR reactions were performed using a Bioer GenePro PCR thermocycler. The amplified PCR products were separated by gel electrophoresis using $1.2 \%$ agarose in $1 \mathrm{X}$ TBE buffer and run at $100 \mathrm{~V}$ for $60 \mathrm{~min}$.

Specificity testing of PCR primers : The specificity of primers were assessed using DNA extracted from a collection of pure bacterial cultures. Eleven isolates of $X c c$ along with nine cultures of other bacteria like $X$. campestris. pv. euvasicatoria, $X$. oryzae pv. oryzae, $X$. axonopodis pv. punicae, $X$. citri subsp. citri, Ralstonia solanacearum, Erwinia caratovora subsp. caratovora, 
Table 1 : Details of bacterial isolates used in this study

\begin{tabular}{llll}
\hline Bacterial species & Bacterial isolates & Host & Place/Source of collection \\
\hline Xanthomonas campestris pv. campestris & Xcc-C218 & Cauliflower & Himachal Pradesh, India \\
& Xcc-C219 & Cauliflower & Himachal Pradesh,India \\
& Xcc- C220 & Cauliflower & Himachal Pradesh,India \\
& Xcc-C221 & Cauliflower & Himachal Pradesh, India \\
& Xcc- C222 & Red cabbage & Himachal Pradesh, India \\
& Xcc-C223 & Cauliflower & Himachal Pradesh, India \\
& Xcc-C224 & Cabbage & Himachal Pradesh, India \\
& Xcc-C211 & Cauliflower & Karnataka, India \\
& Xcc-C197 & Cauliflower & West Bengal, India \\
X. campestris pv. euvasicatoria & Xcc-C201 & Cauliflower & West Bengal, India \\
X. oryzae pv. oryzae & XccP1 & Cabbage & China (During post entry quarantine from \\
X. axonopodis pv. punicae & XCVT-1 & & Syngenta India Limited Research Farm, Karnal) \\
X. citri subsp. citri & BB1 & Tomato & Himachal Pradesh, India \\
Ralstonia solanacearum & - & Rice & Haryana, India \\
Erwinia caratovora subsp. caratovora & - & Pomegranate & ICAR-IARI, New Delhi, India \\
Bacillus subtilis & - & Acid lime & ICAR-IARI, New Delhi, India \\
Pseudomonas fluorescens & - & Tomato & Uttarakhand, India \\
Pseudomonas aeruginosa & - & - & ICAR- NBAIM, Mau, India \\
\hline
\end{tabular}

ICAR-NBAIM: National Bureau of Agriculturally Important Microorganisms; MTCC : Microbial Type Culture Collection and Gene Bank, ICAR-IARI: Indian Agricultural Research Institute

Bacillus subtilis, Pseudomonas fluorescens and Pseudomonas aeruginosa were used for specificity test.

Sensitivity testing of PCR primers : The sensitivity of PCR was tested by using dilution of DNA and bacterial cells separately. To analyse the sensitivity of PCR assay, $100 \mathrm{ng}$ of DNA was diluted from $10^{-1}$ to $10^{-6}$ dilution and PCR amplification was done from each dilution of DNA as template with other PCR components as described earlier. In dilution of cell procedure, the Xcc was grown on YDCA medium for $48 \mathrm{hrs}$ at $28^{\circ} \mathrm{C}$, a single colony was picked using a sterile toothpick and re-suspended in $1 \mathrm{ml}$ of sterile water making a bacterial suspension of approximately $10^{12} \mathrm{CFU}$ $\mathrm{ml}^{-1}$. The sample was thoroughly mixed to ensure uniform distribution of bacteria. The sample was serially diluted in tenfold increments using sterile double distilled water up to a dilution of $10^{-10}$ to give end concentration of cells ranging from $10^{12}$ to $10^{2} \mathrm{CFU} \mathrm{ml^{-1 }}$. From each of the diluted samples, $100 \mu \mathrm{l}$ of the bacterial suspension was plated on YDCA media in duplicate. The samples were incubated at $28^{\circ} \mathrm{C}$ for $48 \mathrm{hrs}$. The colonies formed were manually counted and the CFU ml-1 were calculated using formulae CFU $\mathrm{ml}^{-1}=($ no. of colonies $\mathrm{x}$ dilution factor)/ volume of culture plate. The remaining $800 \mu$ portion of the suspension in each Eppendorf tube was kept at $95^{\circ} \mathrm{C}$ for 5 min and then $4 \mu$ l of it was used as a template in PCR.

\section{Results and Discussion}

The Xcc specific primers were designed from rpfH gene region of rpf family of Xanthomonas campestris pv. campestris str. ATCC 33913 chromosome (Fig.1). The specific primer sequences were tested in silico by BLASTN sequence database (http://www.blast.ncbi.nlm.nih.gov/) of National Center for Biotechnology Information (NCBI) and no significant matches were detected with other Xanthomonas spp. sequences. When genomic DNA sequence of $X_{c c}$ was compared with other Xanthomonad (Xanthomonas axonopodis pv. citri), a significant difference was evident, and one of these differences is in a region contained genes that regulate the expression of pathogenicity factors, the rpf gene (da Silva, 2002). The rpf $\mathrm{H}$ gene from rpf cluster, present in Xcc, was not present in Xac and Xoo (Dow et al., 1994; Potnis et al., 2011). Hence, this difference promoted to develop a new specific diagnostic primer set for Xcc. As PCR assay have been used successfully for the identification and detection of important Xanthomonads such as Xanthomonas campestris pv. musacearum (Adikini et al., 2011), Xanthomonas campestris pv. vesicatoria (Leite et al., 1994; Park et al., 2009), Xanthomonas axonopodis pv. citri (Park et al., 2006), Xanthomonas campestris pv. glycines (Oh et al., 1999) etc., and different specific gene based primers were used for the detection of Xcc like hrpF gene (Park et al., 2004; Berg et al., 2005; Singh et al., 2014), hrcC (Zaccardelli et al., 2007). To the best of our knowledge, rpf gene based primer set was first time explored for specific detection of Xcc.

When specificity test was done using two $X c c$ isolates (Xcc-C218 and Xcc-C219) and other test bacteria, amplification of $304 \mathrm{bp}$ DNA band was observed in both the isolates of Xcc, whereas no amplification was observed in other Xanthomonas 


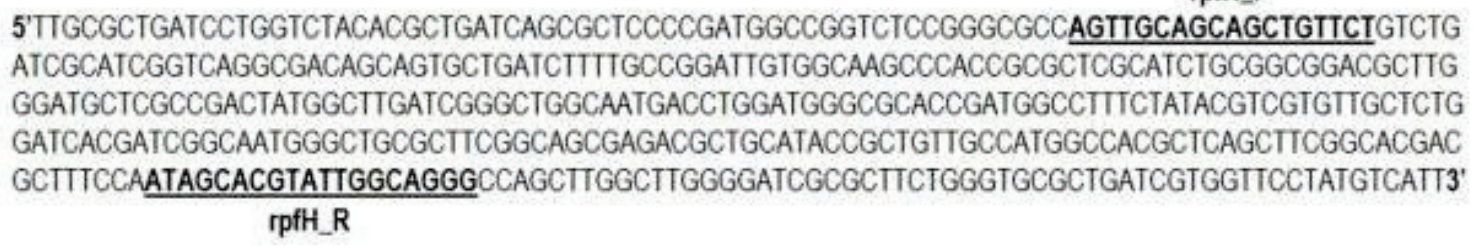

Fig. 1 : Design of specific primer set for $X c c$ based on $r p f H$ gene. Underlined sequences represent nucleotide sequence of forward (rpfH_F) and reverse (rpfH_R) primers.
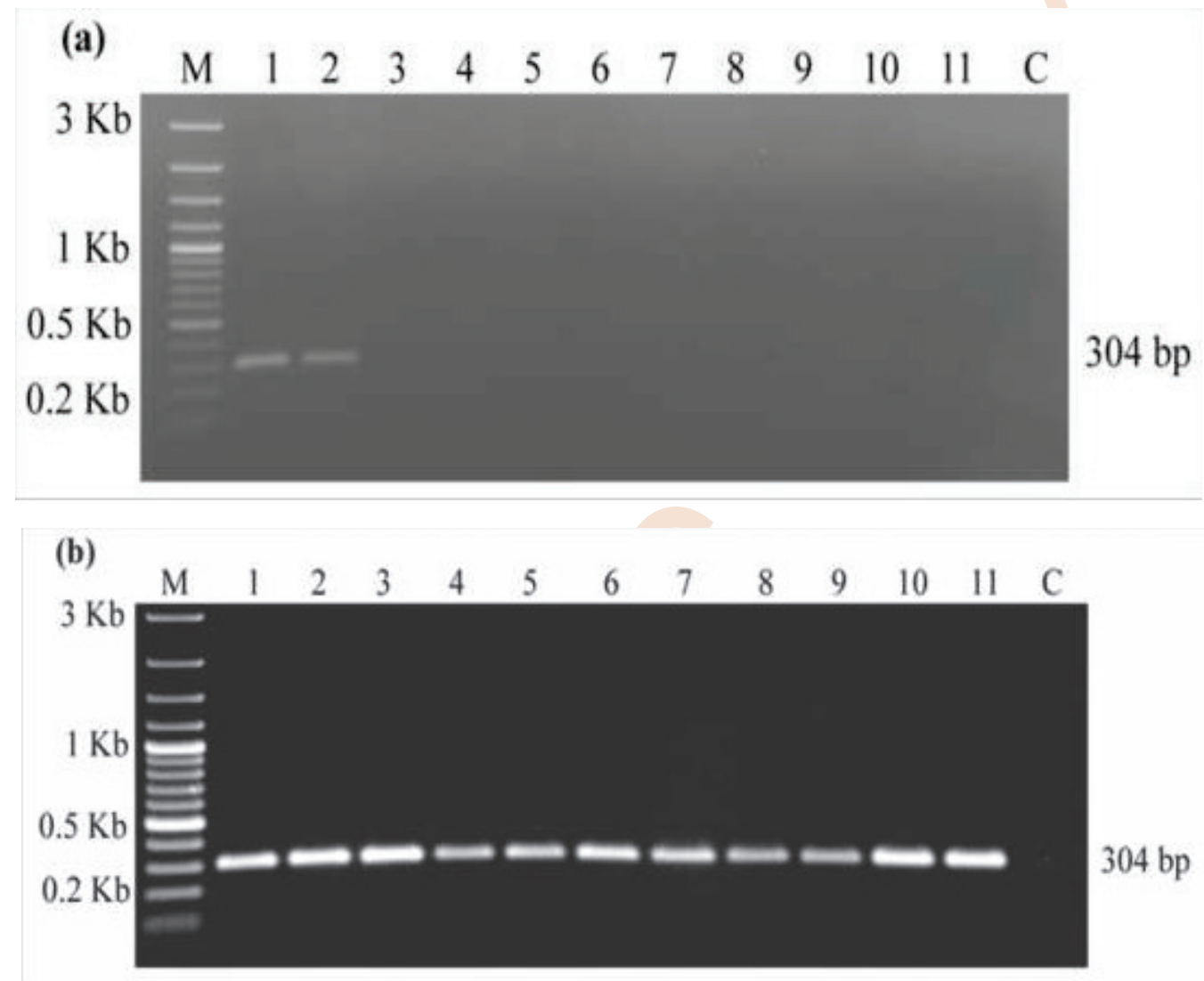

Fig. 2 : Specific amplification of $X$. campestris pv. campestris targets by PCR using primer set rpfH_F and rpfH_R. Lane M-100 bp plus DNA ladder; (a) Lanes 1 and 2-Xcc isolates (Xcc-C218 and Xcc-C219), Lane 3-X. campestris. pv. euvasicatoria, Lane 4-X. oryzae pv. oryzae, Lane 5-X. axonopodis pv. punicae, Lane 6-X. citri subsp. citri, Lane 7- Ralstonia solanacearum, Lane 8- Erwinia caratovora subsp. caratovora, Lane 9- Bacillus subtilis, Lane 10Pseudomonas fluorescens, Lane 11-P. aeruginosa and Lane C-Negative control; (b) Lanes 1 to 11-X. campestris pv. campestris isolates viz. Xcc-C218, Xcc- C219, Xcc- C220, Xcc- C221, Xcc- C222, Xcc- C223, Xcc- C224, Xcc-C211, Xcc-C197, Xcc-C201, XccP1, Lane C- Negative control.

spp. and other test bacteria (Fig. 2a). PCR was performed at different annealing temperature $\left(48\right.$ to $\left.69^{\circ} \mathrm{C}\right)$ and optimum time (30 sec and $45 \mathrm{sec}$ ) using this primer set, with appropriate negative control. It was identified that the best temperature and time for annealing of this primer set was $63^{\circ} \mathrm{C}$ for $45 \mathrm{sec}$. All the eleven $X c c$ isolates used in this study showed positive result by this primer set (Fig. 2b). Similar results were obtained when rpf gene based primers were designed for the detection of Xanthomonas axonopodis pv. citri in infected citrus plants (Coletta-Filho et al., 2006).

Primers sets should not only be specific but also sensitive to detect small quantity of pathogen as these can be used as a diagnostics in quarantine and inspection. These primers were 

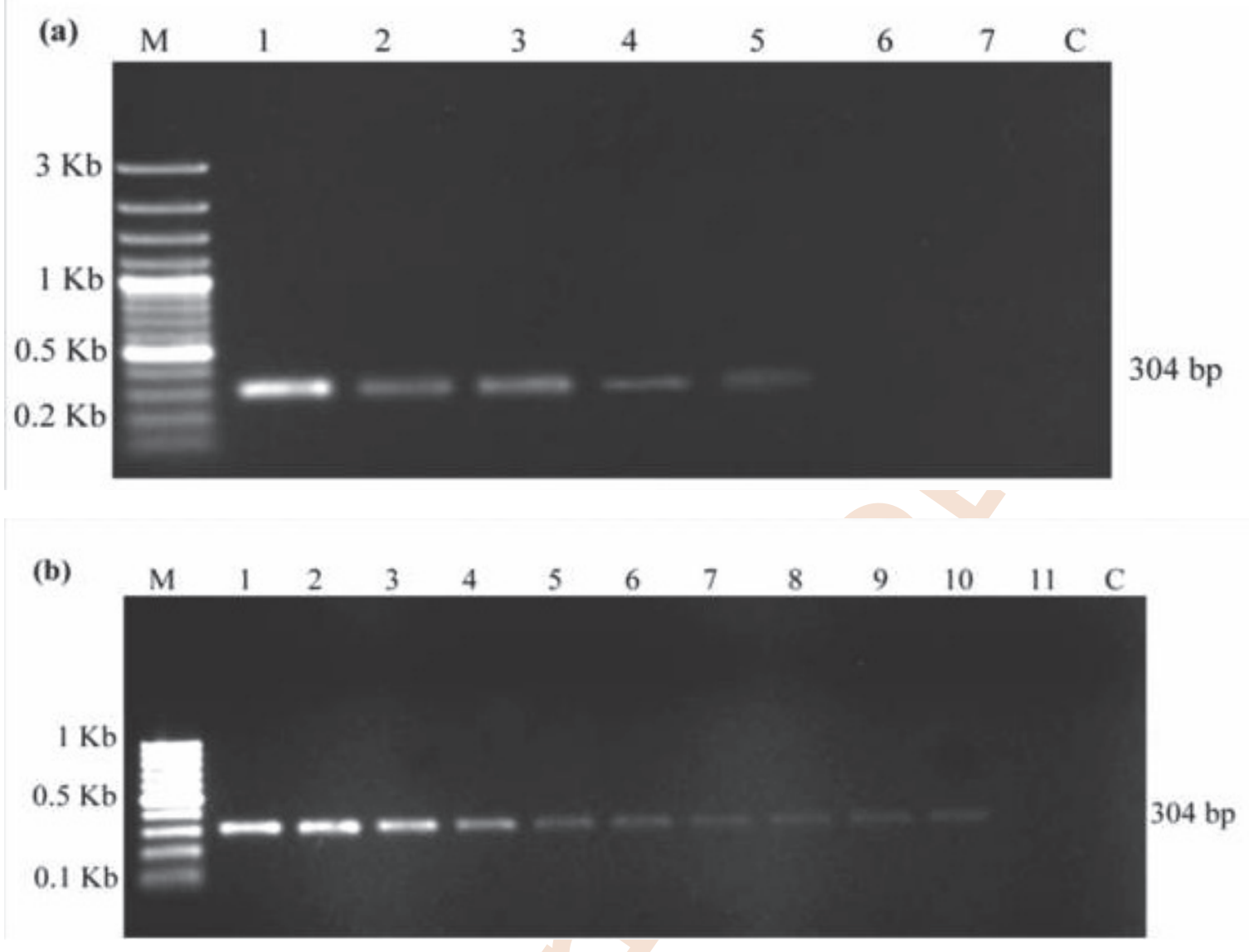

Fig. 3 : Sensitivity of PCR amplification for $X$. campestris pv. campestris using of primer set rpfH_F and rpfH_R; (a) tenfold dilution of DNA.

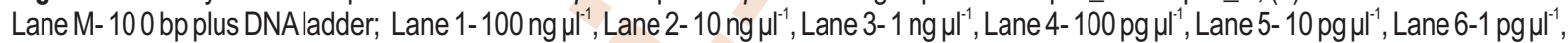

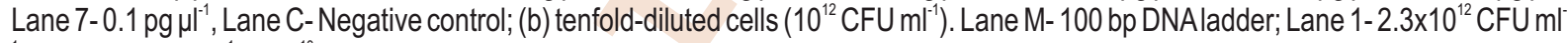
${ }^{1}$; Lanes 2 to $11-10^{-1}$ to $10^{-10}$ dilution.

found highly sensitive as it could detect DNA upto $10 \mathrm{pg}$. The sensitivity of PCR assay was tested by serial dilution of bacterial DNA. A 100 ng concentration of DNA was taken and diluted up to $10^{-6}$ dilution. A single $304 \mathrm{bp}$ amplification was seen in $100 \mathrm{ng}, 10$ $\mathrm{ng}, 1 \mathrm{ng}$ and faint bands were seen in $100 \mathrm{pg}$ and $10 \mathrm{pg}$ concentration of DNA, no amplification was obtained when DNA was further diluted (Fig. 3a). Similar results were reported by Back et al. (2015) where detection limit was $10 \mathrm{pg}_{\mathrm{HI}}{ }^{-1}$ for XPN primer used for detection of $X$. axonopodis pv. poinsettiicola and XHG for the detection of $X$. hyacinthi. Whereas, detection limit was $100 \mathrm{pg}$ $\mu l^{-1}$ DNA of Xcc was reported by Singh et al. (2014) using hrpF gene based primers.

The sensitivity of PCR assay was determined using a ten-fold dilution series of cells of Xcc, the expected PCR fragment product was amplified in sample up to $3 \times 10^{3} \mathrm{CFU} \mathrm{ml}^{-1}$. The initial sample was having $2.3 \times 10^{12} \mathrm{CFU} \mathrm{ml}^{-1}$ and this primer set was able to detect upto $10^{-9}$ dilution i.e., about 12 cells per reaction of PCR (Fig. 3b). Unlike other primers based on hrp region of the $X c c, r p f$ gene based primer set was more sensitive as it has detected upto $3 \times 10^{3} \mathrm{CFU} \mathrm{ml}{ }^{-1}$ (approximately 12 cells per PCR reaction), whereas $h r p$ gene based primers detected

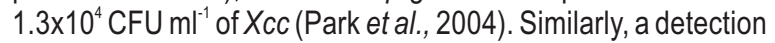
limit of $10^{3} \mathrm{CFU} \mathrm{ml^{-1 }}$ i.e., about 4 cells per reaction was observed in Xanthomonas campestris pv. musacearum using seven primer sets (Adikini et al., 2011).

Black rot of cabbage and cauliflower caused by $X c c$ is very important regulated non-quarantine pathogen (PQ Order 2003, amended till May 2017). The results of this study revealed that this rpf gene based primers were useful for the sensitive, rapid and routine detection of Xcc in quarantine laboratories and probably used in detection of field infected samples and for certification. The fast detection of causal agent of black rot disease also permits timely deployment of control strategies to prevent spread of the disease. 


\section{Acknowledgments}

The authors are thankful to the Indian Council of Agricultural Research, New Delhi for financial support and also grateful for the support and encouragement of the Director, ICARNBPGR, New Delhi.

\section{References}

Adikini, S., L. Tripathi, F. Beed, G. Tusiime, E.M. Magembe and D.J. Kim: Development of a specific molecular tool for detecting Xanthomonas campestris pv. musacearum. Plant Pathol., 60, 443452 (2011).

Back, C.G., S.Y. Lee, B.J. Lee, M.C. Yea, S.M. Kim, I.K. Kang, J.S. Cha and H.Y. Jung: Development of a species-specific PCR assay for three Xanthomonas species, causing bulb and flower diseases, based on their genome sequences. The Plant Pathol. J., 31, 212$218(2015)$

Berg, T., L. Tesoriero and D.L. Hailstones: PCR-based detection of Xanthomonas campestris pathovars in Brassica seed. Plant Pathol., 54, 416-427 (2005).

Coletta-Filho, H.D., M. A. Takita, A.A. de Souza, J.R. Neto, S.A.L. Destefano, J.S. Hartung and M.A. Machado: Primers based on the rpf gene region provide improved detection of Xanthomonas axonopodis pv. citri in naturally and artificially infected citrus plants. J. Appl. Microbiol., 100, 279-285 (2006).

O'Connell, A., S.-Q. An, Y. McCarthy, F. Schulte, K. Niehaus, Y.Q. He, J.L. Tang, R.P. Ryan and J.M. Dow: Proteomics analysis of the regulatory role of Rpf/DSF cell-to-cell signaling system in the virulence of Xanthomonas campestris. Mol. Plant Microbe Interact., 26, 1131-1137 (2013).

Cook, A.A., R.H. Larson and J.C. Walker: Relation of the black rot pathogen to cabbage seed. Phytopathology, 42, 316-320 (1952).

da Silva, A.C. Rasera, J.A. Ferro, F.C. Reinach, C.S. Farah, L.R. Furlan, R.B. Quaggio and C.B. Monteiro-Vitorello: Comparison of the genomes of two Xanthomonas pathogens with differing host specificities. Nature, 417, 459-463 (2002).

Dhar, S. and D. Singh: Performance of cauliflower genotypes for yield and resistance against black rot (Xanthomonas campestris pv. campestris). Indian J. Hort., 71, 197-201 (2014).

Dow, J.M. and M.J. Daniels: Pathogenicity determinants and global regulation of pathogenicity of Xanthomonas campestris pv. campestris. In: Bacterial Pathogenesis of Plants and Animals (Ed.: J.L. Dangl). Springer Berlin Heidelberg, pp. $29-41$ (1994).

Dow, J.M., J. Feng, C.E. Barber, J. Tang and M.J. Daniels: Novel genes involved in the regulation of pathogenicity factor production within the rpf gene cluster of Xanthomonas campestris. Microbiology, 146, 885-891(2000).

Henson, J.M. and R. French: The polymerase chain reaction and plant disease diagnosis. Annu. Rev. Phytopathol., 31, 81-109 (1993).

Kumar, P., R. Kiran, A. Kandan, J. Akhtar, B. Singh, K. Nair and S.C. Dubey: Detection of Xanthomonas campestris pv. campestris in imported germplasm of cabbage during post entry quarantine. Indian Phytopathol., 70, 413-417 (2017).
Leite, R.P., G.V. Minsavage, U. Bonas and R.E. Stall: Detection and identification of phytopathogenic Xanthomonas isolates by amplification of DNA sequences related to the hrp genes of Xanthomonas campestris pv. vesicatoria. Appl. Environ. Microbiol., 60, 1068-1077 (1994).

Oh, C., S. Heu and Y. Choi: Sensitive and pathovar-specific detection of Xanthomonas campestris pv. glycines by DNA hybridization and polymerase chain reaction analysis. Plant Pathol. J., 15, 57-61 (1999).

Park, D.S., J.W. Hyun, Y.J. Park, J.S. Kim, H.W. Kang, J.H. Hahn and S.J. Go: Sensitive and specific detection of Xanthomonas axonopodis pv. citri by PCR using pathovar specific primers based on hrpW gene sequences. Microbiol. Res., 161, 145-149 (2006).

Park, D.S., J.K. Shim, J.S. Kim, C.K. Lim, R. Shrestha, J.H. Hahn and H.G. Kim: Sensitive and specific detection of Xanthomonas campestris pv. vesicatoria by PCR using pathovar-specific primers based on rhs family gene sequences. Microbiol. Res., 164, 36-42 (2009).

Park, Y.J., B.M. Lee, J. Ho-Hahn, G.B. Lee and D.S. Park: Sensitive and specific detection of Xanthomonas campestris pv. campestris by PCR using species-specific primers based on hrpF gene sequences. Microbiol. Res., 159, 419-423 (2004).

Pitcher, D.G., N.A. Saunders and R.J. Owen: Rapid extraction of bacterial genomic DNA with guanidium thiocyanate. Lett. Appl. Microbiol., 8, 151-156 (1989).

Plant Quarantine (Regulation of Import into India) Order 2003: The Gazette of India Part II Section-3-Sub-section (ii) published by Ministry of Agriculture (Department of Agriculture \& Cooperation) Notification, New Delhi, p. 104 (2003).

Potnis, N., K. Krasileva, V. Chow, N.F. Almeida and P.B. Patil: Comparative genomics reveals diversity among Xanthomonads infecting tomato and pepper. BMC Genomics, 12, 146 (2011).

Singh, D. and S. Dhar: Bio-PCR based diagnosis of Xanthomonas campestris pv. campestris in black rot of infected leaves of crucifers. Indian Phytopathol., 64, 7-11 (2011).

Singh, D., B.T. Raghavendra, P. S. Rathaur, H. Singh, R. Raghuwanshi and R.P. Singh: Detection of black rot disease causing pathogen Xanthomonas campestris pv. campestris by bio-PCR from seeds and plant parts of cole crops. Seed Sci. Technol., 42, 36-46 (2014).

Slater, H., A. Alvarez-Morales, C.E. Barber, M.J. Daniels and J.M. Dow: A two-component system involving an HD-GYP domain protein links cell-cell signalling to pathogenicity gene expression in Xanthomonas campestris. Mol. Microbiol., 38, 986-1003 (2000).

Tang, J.L., Y.N. Liu, C.E. Barber, J.M. Dow, J.C. Wootton and M.J. Daniels: Genetic and molecular analysis of a cluster of $r p f$ genes involved in positive regulation of synthesis of extracellular enzymes and polysaccharide in Xanthomonas campestris pv. campestris. Mol. Gen. Genet., 226, 409-417 (1991).

Williams, P.H.: Black rot: A continuing threat to world crucifers. Plant Dis., 64, 736-742 (1980).

Zaccardelli, M., F. Campanile, A. Spasiano and M. Merighi: Detection and identification of the crucifer pathogen, Xanthomonas campestris pv. campestris, by PCR amplification of the conserved Hrp/ type III secretion system gene hrcC. Eur. J. Plant Pathol., 118, 299-306 (2007). 